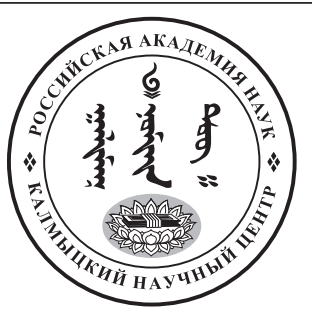

Published in the Russian Federation

Oriental Studies (Previous Name: Bulletin of the Kalmyk Institute

for Humanities of the Russian Academy of Sciences)

Has been issued as a journal since 2008

ISSN: 2619-0990; E-ISSN: 2619-1008

Vol. 13, Is. 1, pp. 208-223, 2020

DOI: $10.22162 / 2619-0990-2020-47-1-208-223$

Journal homepage: https://kigiran.elpub.ru

УДК 811.512 .153

\title{
Модели элементарных простых предложений каузированного перемещения объекта в пространстве (на материале хакасского языка)
}

\section{Алена Николаевна Чугунекова ${ }^{1}$}

${ }^{1}$ Хакасский государственный университет им. Н. Ф. Катанова (д. 94, пр. Ленина, 655017 Абакан, Российская Федерация)

доктор филологических наук, доцент, ведущий научный сотрудник

iD 0000-0003-1046-5699. E-mail: Chugunekowa@yandex.ru

(C) КалмНЦ РАН, 2020

(C) Чугунекова А. Н., 2020

Аннотация. Введение. Настоящая статья посвящена модельному описанию простого предложения хакасского языка, а именно моделям элементарных простых предложений каузированного перемещения объекта в пространстве. В настоящее время многие вопросы, касающиеся описания элементарного простого предложения в хакасском языке, еще не получили должного освещения, чем и определяется актуальность данного исследования. Цель статьи - выявление и анализ структурно-семантических моделей элементарных простых предложений перемещения объекта в хакасском языке. Материалом исследования послужила сплошная выборка примеров из художественных произведений хакасских писателей, фольклорных текстов, публицистики, а также записи устной речи. Результатыл. На основе проведенного исследования автор приходит к выводу, что в составе предложения каузированного перемещения объекта в пространстве объединяются модели адлокативного, делокативного и транслокативного перемещения. Данная модель, кроме обязательных актантов (субъекта и локализатора), требует еще и позиции объекта перемещения. На основании проделанной работы мы можем утверждать, что перемещение в одной модели более трех актантов одновременно для хакасского языка малохарактерно. Адлокативная модель характеризует каузированное перемещение объекта по направлению к какой-либо точке, делокативная модель представляет собой каузированное перемещение объекта от какой-либо точки в пространстве, транслокативная модель - каузированное перемещение объекта по какой-либо трассе. У каждой модели содержится описание типовой семантики, список наиболее характерных для каждой модели глаголов, способ оформления локализатора и конкретных примеров, иллюстрирующих их употребление. Каждая модель варьируется в семантическом и структурном планах. У адлокативной модели в зависимости от семантики локализатора выделяются 11 вариантов; у делокативной модели - 8; у транслокативной - 6. Локализатор адлокативной модели оформлен именем существительным в направительном падеже (показатель — =зар/=зер; $=c a p /=c e p)$, реже - дательным (показатель $-=2 a /=2 e ;=x a /=\kappa e ;=a /=e)$, сочетанием имени существительного с послелогом и служебными 
именами в направительном падеже, дейктическими локативными наречиями; делокативный

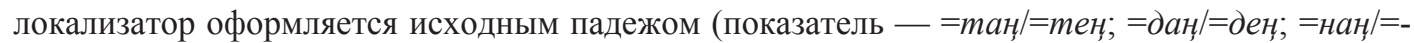
нең), сочетанием имени существительного с послелогами и служебными именами в исходном падеже, дейктическими локативными наречиями; транслоктивному локализатору свойственен продольно-направительный падеж (показатель — = чa/че; =ya/=ye), дейктические локативные наречия и сочетание имени существительного со служебными именами в продольно-направительном падеже.

Ключевые слова: модель адлокативного перемещения, модель делокативного перемещения, модель транслокативного перемещения, предикаты перемещения, локализатор, объект перемещения, каузативный глагол, хакасский язык

Для цитирования: Чугунекова А. Н. Модели элементарных простых предложений каузированного перемещения объекта в пространстве (на материале хакасского языка). Oriental Studies. 2020. T. 13. № 1. C. 208-223. DOI: 10.22162/2619-0990-2020-47-1-208-223

UDC 811.512.153

\section{Causal Spatial Object Relocation: Models of Elementary Simple Sentences (a Case Study of the Khakas Language)}

\section{Alyona N. Chugunekova}

${ }^{1}$ Katanov Khakas State University (94, Lenin Ave., Abakan 655017, Russian Federation)

Dr. Sc. (Philology), Associate Professor, Leading Research Associate

iD 0000-0003-1046-5699. E-mail: Chugunekowa@yandex.ru

CKalmSC RAS, 2020

(C) Chugunekova A. N., 2020

Abstract. Goals. The article identifies and analyzes models of elementary simple sentences of causal spatial object relocation based on the structural scheme $\left\{\mathrm{N}^{\mathrm{S} \text {-causr }}{ }_{\mathrm{Nom}} \mathrm{N}^{\text {Ob-causv }}{ }_{\text {Acc }}\right.$ AdlocDelocTrloc $\left.\mathrm{V}_{\text {fin }}\right\}$. Materials. The proposals of this block diagram are based on the hypermodel of causal spatial object relocation which combines models of adlocative, delocative, and translocative movement. The causal model, in addition to the mandatory actants (subject and localizer), also requires the position of the moving object be identified. Results. The work shows that relocation of more than three actants in one model is not that typical for the Khakas language (though there are some separate examples). The adlocative model characterizes casual object relocation towards a certain point, the delocative model describes causal object relocation from any point in space, and the translocative model stands for causal object relocation along some track. Each model contains a description of typical semantics, list of most characteristic verbs used, means to delineate the localizer, and specific examples that illustrate their use. Each model varies both semantically and structurally. The adlocative model may have up to 11 variants depending on semantics of the localizer; delocative model -8 variants; translocative model - 6 variants. A localizer of the adlocative model is represented by a noun in the aditive case (marker — = $=3 a p /=3 е p ;=c a p /=c e p)$, less often - in the dative (marker $-=z a /=2 e$;

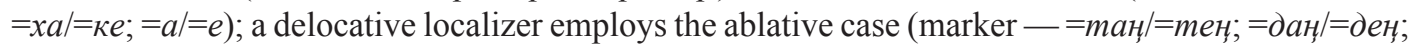
$=н а ң /=н е ң) ;$ translocative localizers are characterized by the use of the axial-aditive case (marker $=$

Keywords: verbs of movement, adlocative model, delocative model, translocative model, relocation predicates, localizer, causator, Khakas language

For citation: Chugunekova A. N. Causal Spatial Object Relocation: Models of Elementary Simple Sentences (a Case Study of the Khakas Language). Oriental Studies. 2020. Vol. 13. No. 1. Pp. 208223. (In Russ.). DOI: 10.22162/2619-0990-2020-47-1-208-223 


\section{है}

\section{Введение}

Модели простых предложений каузированного перемещения объекта занимают особое место в системе пространственных моделей. На материале разных языков они были объектом внимания многих исследователей. Так, например, в русском языке Т. В. Шмелева [Шмелева 1988] рассматривает их как разновидность бытийно-пространственных моделей предложения, сближая их с моделями движения на основе «общего набора ролей локализаторов (кто - перемещается - куда - откуда - по какой трассе - при помощи транспортного средства)» [Кошкарева 2004: 72]. Н. Б. Кошкарева в хантыйском языке выделяет эту модель как самостоятельную, в которой описывается «каузация различных видов действия» [Кошкарева 2004: 76].

И. А. Невская, разработавшая структуру и семантику локативных конструкций в тюркских языках Южной Сибири, среди элементарных динамических локативных конструкций выделяет конструкции адлокачฺии, делокачии и транслокации. В каждой из этих конструкций выделяются конструкции каузированного перемещения объекта в пространстве [Невская 2005: 192]. В ненецком языке наряду с некаузативными адлокативными моделями подробно описаны адлокативные модели каузативного перемещения [Шилова 2003б: 89]. М. В. Дурова, как и вышеуказанные авторы, рассмотрела каузативные адлокативные модели для японского языка. Ею выявлены и описаны 5 основных типов моделей в соответствии со значением глагольного предиката и способа оформления локализатора [Дурова 2012: 77].

В хакасском языке предложения с семантикой каузированного перемещения объекта наряду с предложениями движения, местонахождения, существования [Чугунекова 2019] строятся по разным моделям элементарного простого предложения (далее - ЭПП). Понятие ЭПП в научный оборот было введено М. И. Черемисиной и Т. А. Колосовой [Черемисина, Колосова 1987: 13] и продолжает развиваться в трудах исследователей новосибирской синтак- сической школы, которые используют для представления этой основной единицы синтаксиса метод структурно-семантического моделирования [Телякова 1994; Серээдар 1995; Невская 1997; Невская 2005; Шилова 2003; Соловар 1991; Соловар 2011; Кошкарева 2004; Кошкарева 2005; Кошкарева 2006; Черемисина, Озонова, Тазранова 2008; Озонова 2012; Дурова 2016; и др.].

Под ЭПП мы понимаем минимальную двустороннюю единицу языка, которая обладает как формальной (структурной схемой), так и содержательной стороной (пропозицией).

Одна из основных характеристик, по которым выделяется ЭПП, - это минимальность (содержит только те компоненты, которые строго необходимы для описания некоторой ситуации). Базовым компонентом ЭПП выступает его сказуемое («единственный независимый его член» [Невская 2005: 43]). Все другие члены ЭПП зависят от него и заполняют все его обязательные валентности. Каждое ЭПП строится по разным моделям: «план выражения модели есть структурная схема, отражающая компоненты, необходимые и достаточные для выражения минимальной обобщенной пропозиции, план содержания модели составляет пропозиция, выражаемая синтаксической формой. Все необходимые компоненты структурной схемы фиксируются в ней при помощи условных символов, которые соответствуют частям речи и содержат грамматические дескрипторы нижнего и верхнего индекса» [Черемисина 1995; Соловар 1991; Соловар 2011; Скрибник 1990; Телякова 1994; Серээдар 1995; Серээдар 1996; Невская 1997; Невская 2005; Шилова 2003а; Шилова 2003б; Байжанова 2004; Дурова 2012; Дурова 2016], многообразие речевых воплощений конкретной модели представляет собой ее структурное и семантическое варьирование» [Черемисина, Скрибник 1996: 48].

Дескрипторы нижнего индекса представляют грамматические характеристики компонента модели. Например, символом $\mathrm{N}_{\text {Nом }}$ фиксируется имя существительное в именительном падеже, а дескриптором 
верхнего индекса $\left(\mathrm{N}^{\mathrm{S}-\mathrm{causr}}\right)$ - семантические роли компонентов модели.

Модель ЭПП перемещения «описывает типовую ситуацию перемещения в физической, интеллектуальной, социальной и др. сферах» [Кошкарева 2005: 102]. Такие предложения характеризуются наличием в своем составе следующих компонентов: субъект, объект, предикат, директив-старт (начальная точка перемещуения), директив-финиш (конечная точка перемещуения), трасса перемещения. Наличие в составе рассматриваемого предложения позиции объекта говорит о каузативном характере предложения, т. е. «объект совершает движение не самостоятельно, а под воздействием субъекта-каузатора» [Кошкарева 2004: 72].

Полная структурная схема модели ЭПП перемещения может выглядеть следующим образом: $\left\{\mathrm{N}^{\text {S-causr }}{ }_{\text {NOM }} \mathrm{N}_{\text {ACC }}^{\text {Ob-causv }}\right.$ Adloc Deloc Trloc $\mathrm{V}_{\text {caus }}^{\text {fin. }}$, где $\mathrm{N}_{\text {Nom }}^{\mathrm{S} \text {-causr }}$ - субъект-каузатор, $\mathrm{N}_{\text {Acc }}^{\text {Ob-causv }}$ - объект-каузатив, Adloc - адлокативный локализатор (финишная точка), Deloc - делокативный локализатор (стартовая точка), Trloc - транслокативный локализатор (трасса), $\mathrm{V}^{\text {caus }}$ - каузативный предикат перемещения.

Все позиции модели реализуются крайне редко; обычно в предложении встречаются один или два локализатора. В связи с этим для хакасского языка мы выделяем следующие модели элементарных простых предложений перемещения объекта:

1) $\left\{\mathrm{N}_{\text {NOM }}^{\text {-causr }} \mathrm{N}_{\text {ACC }}^{\text {Ob-causv }}\right.$ Adloc $\left.\mathrm{V}_{\text {fin. }}^{\text {caus }}\right\}$ - модель адлокативного перемещения;

2) $\left\{\mathrm{N}_{\text {NOM }}^{\mathrm{S} \text {-causr }} \mathrm{N}_{\text {aCC }}^{\text {Ob-causv }}\right.$ Deloc $\left.\mathrm{V}_{\text {caus }}{ }_{\text {fin. }}\right\}-$ модель делокативного перемещения;

3) $\left\{\mathrm{N}_{\text {NOM }}^{\text {S-causr }} \mathrm{N}_{\text {ACC }}^{\text {Ob-causv }}\right.$ Trloc $\left.\mathrm{V}_{\text {fin. }}^{\text {caus }}\right\}-$ модель транслоктивного перемещения.

Термины «адлокация», «делокация» и «транслокация» активно используются при описании пространственных моделей предложения исследователями новосибирской синтаксической школы [Невская 1997; Невская 2005; Кошкарева 2004; Кошкарева 2005; Шилова 2003а; Шилова 2003б; Дурова 2012; Дурова 2016; и др.], которые мы в своей работе вслед за ними тоже используем, включая символы, введенные для представления структурной схемы предложений.

Ситуация перемещения может реализовываться как в «физической сфере», так и в «психической», «интеллектуальной» и «социальной сферах» [Кошкарева 2004: 71].
В данной статье мы ограничились описанием моделей предложения, описывающих ситуацию перемещения в «физической сфере». Основная цель данного исследования заключается в выявлении и описании синтаксических единиц хакасского языка со значением пространства, а именно системы синтаксических единиц, описывающих каузируемое перемещение объекта в пространстве.

\section{Материалы и методы исследования}

Фактическим материалом исследования послужила сплошная выборка примеров из текстов произведений художественной литературы различных жанров, фольклорных и публицистических текстов на хакасском языке, а также примеры, созданные автором статьи - носителем хакасского языка.

Основным методом исследования является метод структурного моделирования предложения, сущность которого заключается в выделении из речи образцов (моделей), по которым строится высказывание.

\section{1. Модель адлокативного перемещения}

$$
\left\{\mathrm{N}_{\text {NOM }}^{\text {-causr }} \mathrm{N}_{\text {ACC }}^{\text {Ob-causv }} \text { Adloc } \mathrm{V}_{\text {fin. }}^{\text {caus }}\right\}
$$

«перемещение объекта по направлению к определенной точке пространства»

Модель адлокативного перемещения объекта представляет перемещение каузируемого объекта по направлению в какой-либо точке в пространстве. В состав модели входят четыре компонента: 1) субъект-каузатор; 2) объект-каузатив; 3 ) адлокативный локализатор; 4) предикат перемещения.

Субъект-каузатор выражен именем существительным в именительном падеже, обозначающим лицо, а также название какой-либо стихии (чаще ветер, вода), исключающей «целенаправленность действия» [Кошкарева 2019: 268]. Позицию объекта-каузатора занимают имена существительные в винительном падеже (=ны). Локализатор представлен именем существительным в направительном падеже (=зар) (реже - дательном (=га)), именем существительным в сочетании с послелогами или служебными именами, а также дейктическими локативными наречиями.

Предикаты выражены глаголами перемещения: авыл- 'принести, привести', ал nap-/ anap- 'нести, везти', сӧзір- '1) тащить, тянуть, волочить кого-л., что-л.; 2) тянуть 
на буксире', сӧӧрте- 'тащить, тянуть', сӱр- 'гнать, выгонять' [ХРC 2006: 532], im'толкать', mapm- 'тянуть, тащить, двигать, придвигать', ыс- 'отправлять', чидін- 'вести кого-л. за руку, уздечку (коня)', чала 'выгонять скот на пастбище', хоста- 'гнать, отгонять кого-л.' и глаголами движения, принявших каузативные аффиксы: кизір- '1) переводить, перевозить кого-л., что-л. через что-л., 2) переправлять кого-л., что-л.', азыр- 'переносить, перевозить, перегонять кого-л., что-л. через что-л.'; кир- 'вводить, впускать, загонять, заводить кого-л., что-л. куда-л.', сыzар- 'выводить , выгонять ко- го-л. поднимать вверх’, чылдыр- 'двигать кого-л., что-л.', кӧзір- 'перемещать, переносить, перетаскивать кого-л., что-л.; перевозить, переселять кого-л., что-л.' [ХРС 2006: $28,67,139,507,596,853,963,1036]$. В хакасском языке при формировании моделей перемещения также участвуют сложные глаголы, образованные от деепричастия mӱзіре (тӥзіре тарт 'тянуть вниз', тӥзіре cac 'толкать вниз', тӥзіре im- 'толкать, двигать вниз'), которые служат для выражения перемещения объекта сверху вниз:

(1) Олар хазыраны иблеріне апарирлар [Хакасские народные 1986: 137]

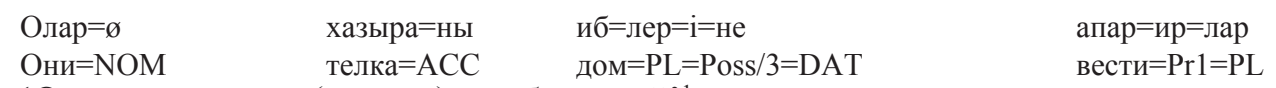

'Они ведут телку (корову) к себе домой'

(2) Алыптар Алтылн Кӧӧкті пуларның чиріне кӧзір килгеннер [ХНС 1986: 7]

\begin{tabular}{|c|c|c|c|}
\hline Алып=тар & Алтын Коок=ті & пу=лар=ның & чир $=\mathrm{i}=$ не \\
\hline $\begin{array}{l}\text { Богатырь=PL } \\
\text { перевозить=CV1 }\end{array}$ & $\begin{array}{l}\text { Алтын Коок= АCC } \\
\text { кил=ген=нер }\end{array}$ & это $=\mathrm{PL}=\mathrm{GEN}$ & земля $=\mathrm{POSS} / 3=\mathrm{DAT}$ \\
\hline
\end{tabular}

AUX: приходить $=$ PAST $1=P L$

'Богатыри перевезли Алтын Коок на их землю'.

В зависимости от семантики локализа- себя» [Апресян 1995: 636]; mizдер кач. (разг. тора мы выделяем 11 вариантов адлокатив- тігзер) 'туда, в ту сторону', т. е. место, на ной модели:

1. Дейктический вариант модели $\left\{\mathrm{N}^{\mathrm{S}-}\right.$ ${ }_{\text {NOM }}^{\text {causr }} \mathrm{N}_{\text {ACC }}^{\text {Ob-causv }}$ Deic $\left.\mathrm{V}_{\text {fin. }}^{\text {caus }}\right\}$ - «перемещение объекта относительно 'дейктического центра' (т. е. говорящего лица)». Локализатор оформлен дейктическими наречиями мындар 'сюда, в эту сторону', т. е. это место, где «говорящий находится или мыслит которое можно непосредственно указать из точки, где находится говорящий («дейксис указательного жеста, пространство собеседника») и андар 'туда', т. е. в более удаленное пространство, возможно за пределами видимости, в которое «говорящий себя не включает» [Невская 2005: 28]:

\section{(3) Піс оларны андар ал пар салвабыс}

$\begin{array}{lllll}\text { Пiс=ø } & \text { олар=ны } & \text { ан=дар } & \text { апар } & \text { сал=ға=быс } \\ \text { Мы=NOM } & \text { они=ACC } & \text { то=LAT } & \text { вести=CV1 } & \text { AUX: класть=PAST1=1PL }\end{array}$

'Мы их отвезли туда (т. е. на то место, в которое себя говорящий не включает, возможно, за пределами его видимости').

2. Директивный вариант модели $\left\{\mathrm{N}^{\mathrm{s}-}\right.$ ${ }_{\text {nOM }}^{\text {causr }} \mathrm{N}_{\text {ACC }}^{\text {Ob-causv }}$ Dir-lat $\left.\mathrm{V}_{\text {caus }}^{\text {ch }}\right\}-$ «перемещение объекта по направлению к чему-ли- бо». Локализатор выражен именем в направительном падеже:

\section{(4) Агафья Карповна пабазын ибзер сӧӧртеп килген [Татарова 1991: 16]}

$\begin{array}{llll}\text { Агафья Карповна }=\varnothing & \text { паба }=\text { =ы }=\mathrm{H} & \text { иб=зер } & \text { сӧӧрте }=\text { п } \\ \text { Агафья Карповна }=\mathrm{NOM} & \text { отец=POSS } 3=\mathrm{ACC} & \text { дом=LAT } & \text { тащить=CV1 }\end{array}$

\footnotetext{
${ }^{1}$ Перевод всех примеров на русский язык осуществлен автором статьи.
} 
AUX: приходить=PAST1

'Агафья Карповна притащила отца домой'.

(5) Казарны мин пу кӧлзер авылвам [Татарова 1991: 210]

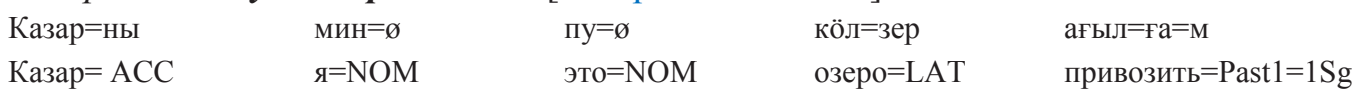

'Казара я привезла на это озеро'.

При глаголе ыс- 'посылать, отправлять' осуществляется каузированное перемещение объекта по направлению к точке про- странства без физического контакта с ним субъекта-каузатора, например:

(6) Казан ипчізін имчілерзер ызыбысхан [Татарова 1991: 123]

$\begin{array}{llll}\text { Казан }=0 & \text { ипчi=3i=H } & \text { имчі=лер=зер } & \text { ыз=ыбыс=хан } \\ \text { Казан=NOM } & \text { жена=POSS } / 3=\text { ACC } & \text { врач=PL=LAT } & \text { отправлять=PFV=PAST1 }\end{array}$

'Казан отправил жену к врачам'.

(7) Мині сірерзер ыстылар [Чарков1994: 138]

$\begin{array}{lll}\text { Мин=i } & \text { cipep=зер } & \text { ыс=ты=лар } \\ \text { Я=ACC } & \text { вы=LAT } & \text { отправлять=PAST2=PL }\end{array}$

'Меня отправили к вам'.

3. Антелативный вариант модели $\left\{\mathrm{N}^{\mathrm{s}-}\right.$ ${ }_{\text {NOM }}^{\text {causr }} \mathrm{N}^{\text {Ob-causv }}{ }_{\text {ACC }}$ Antelat $\left.\mathrm{V}_{\text {fin }}^{\text {caus }}\right\}-$ «перемещение объекта в сторону передней части пространства». Локализатор выражен сочетанием имени существительного со служебным именем алнынзар 'вперед':

(8) Манзар адын иб алнынзар чидін килир [Балтыжаков 1975: 64]

\begin{tabular}{|c|c|c|c|}
\hline Манзар $=0$ & ад $=\mathrm{b}=\mathrm{H}$ & иб $=0$ & алн=ы=нзар \\
\hline $\begin{array}{l}\text { Манзар=NOM } \\
\text { чидін }\end{array}$ & $\begin{array}{l}\text { конь }=\mathrm{POSS} / 3=\mathrm{ACC} \\
\text { кил=ир }\end{array}$ & дом $=$ Nom & перед= POSS $/ 3=\mathrm{LAT}$ \\
\hline
\end{tabular}

4. Терминативный вариант модели $\left\{\mathrm{N}^{\mathrm{S}}\right.$ CAUSR ${ }_{\text {NOM }} \mathrm{N}^{\mathrm{Ob}-\mathrm{CAUSV}}{ }_{\text {ACC }}$ Termin $\left.\mathrm{V}^{\text {caus }}{ }_{\text {fin }}\right\}-\ll \Pi \mathrm{e}-$ ремещение объекта до определенного пространственного ориентира». Локализатор выражен именем существительным в да- тельном падеже в сочетании с послелогами читіре 'до' и теере 'до', которые и указывают на предельный характер развития перемещения в пространстве:

(9) Акай Ларисаны поездке читіре авыл салган [Халларов 1984: 109]
Акай $=0$
Лариса $=$ ны
поезд=ке
читіре
ағыл
Акай $=\mathrm{NOM}$
Лариса $=$ ACC
поезд=DAT
до $=$ POSTP
приводить $=\mathrm{CV} 1$

сал=ған

AUX: класть $=$ PAST1

'Акай привез Ларису до самого поезда'.

5. Иллативный вариант модели. Данный вариант имеет две разновидности:

a) $\left\{\mathrm{N}^{\mathrm{S}-\mathrm{CAUSR}}{ }_{\mathrm{NOM}} \mathrm{N}^{\mathrm{Ob}-\mathrm{CAUSV}}{ }_{\text {ACC }}\right.$ Illat $\left.{ }_{1} \mathrm{~V}_{\text {fin }}^{\text {caus }}\right\}$ - «перемещение объекта внутрь ограниченного пространства». Локализатор выражен именем в направительном падеже, обозначающим какое-либо ограниченное пространство. Предикатом выступает глагол перемещения кир, а также сложные глаголы, образованные при помощи деепричастия кире (кире тарт 'тянуть внутрь', кире чылдыр 'толкать внутрь', кире сӥр 'загонять внутрь' и др.), например: 
(10) Чайаачы ус аны [хоосханы] чабанның туразынзар кирібіскен [Султреков 2009: 102] Чайаачы ус $=0$ $\mathrm{a}=$ ны $[$ хоосха $=$ ны $] \quad$ чабан $=$ ның

тура $=$ $=$ ы $=$ нзар Мастер $=\mathrm{NOM}$ $\mathrm{oн}=\mathrm{ACC}[$ кошка $=\mathrm{ACC}] \quad$ чабан $=\mathrm{GEN}$ дом $=\mathrm{POSS} / 3=\mathrm{LAT}$ кир $=$ iбіс $=$ кен впускать $=\mathrm{PFV}=\mathrm{PAST} 1$

'Мастер впустил котёнка в дом чабана'.

(11) Кізілер тиріглерін вагоннарзар кире тазыпчалар [Чарков 1994: 117].
Кізі=лер
тиріг $=$ лер $=\mathrm{i}=\mathrm{H}$ вагон=нар=зар
кире
Человек=PL
инструмент $=\mathrm{PL}=\mathrm{POSS} / 3=\mathrm{ACC} \quad$ вагон $=\mathrm{PL}=\mathrm{LAT}$
внутрь $=$ POSTP
тазы $=\Pi=$ ча $=$ лар.
таскать $=\mathrm{CV} 1=\mathrm{Pr} 2=\mathrm{PL}$
'Люди затаскивают в вагоны инструменты'.

б) $\left\{\mathrm{N}^{\mathrm{S} \text {-causr }}{ }_{\mathrm{NOM}} \mathrm{N}^{\text {Ob-causv }}{ }_{\text {ACC }}\right.$ Illat $\left._{2} \mathrm{~V}_{\text {caus }}^{\text {cin }}\right\}-$ «перемещение объекта в пойму реки, доли- ны». Локализатор выражен именем в направительном падеже в сочетании со служебным именем істінзер 'внутрь':

(12) Гриша чылдызын ӧзен істінзер чалабысхан [Чарков 1994: 146]

\begin{tabular}{|c|c|c|c|}
\hline Гриша=0 & чылғы=зы=н & ӧзен $=0$ & $\mathrm{icT}=\mathrm{i}=$ нзер \\
\hline $\begin{array}{l}\text { Гриша=NOM } \\
\text { чала }=\text { быс }=\text { хан }\end{array}$ & табун $=\mathrm{POSS} / 3=\mathrm{ACC}$ & лог $=$ Nom & нутро $=\mathrm{POSS} / 3=\mathrm{LAT}$ \\
\hline
\end{tabular}

Следует отметить, что при глаголе чалакаузируемым объектом может быть только животное.

6. Аутлативный вариант модели $\left\{\mathrm{N}^{\mathrm{s}-}\right.$ $\underset{\text { NOM }}{\text { causr }} \mathrm{N}_{\text {ACC-caus }}$ Autlat $\left.\mathrm{V}_{\text {caus }}^{\text {fin }}\right\}-$ «переме-

(13) Палаларны тасхар сызарыбысхабыс
Пала=лар $=$ ны
Ребенок $=\mathrm{PL}=\mathrm{ACC}$
$\mathrm{Tac}=\mathrm{xap}$
улица $=$ LAT
'[Мы] детей вывели на улицу'.

7. Апудлативный вариант модели $\left\{\mathrm{N}^{\mathrm{s}-}\right.$ causr ${ }_{\text {NOM }} \mathrm{N}^{\text {Ob-causv }}{ }_{\text {ACC }}$ Apudllat $\left.\mathrm{V}_{\text {caus }}^{\text {can }}\right\}-$ «перемещение объекта к краю, основанию че- щение объекта за пределы ограниченного пространства (наружу)». Локализатор выражен пространственным наречием тасхар ‘наружу, на улицу':

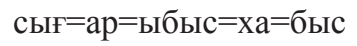

выходить $=$ CAUS $=$ PFR $=$ PAST $1=1 \mathrm{PL}$

го-либо». Локализатор выражен именем существительным в сочетании со служебным именем хыринзар 'к краю чего-л.', хазынзар 'к краю берега реки, дороги':

\section{(14) Піс хапты тура хыринзар сӧортеп салвабыс}

$\begin{array}{lllll}\Pi \text { Піс }=\varnothing & \text { хап }=\text { ты } & \text { тура }=0 & \text { хыр }=\text { и=ензар } & \text { сӧӧрте }=\text { П } \\ \text { Мы }=\text { NOM } & \text { мешок }=\text { ACC } & \text { дом }=\text { NOM } & \text { край }=\text { POSS } / 3=\text { LAT } & \text { тащить }=\text { CV1 }\end{array}$

сал $=$ ға $=$ быс

AUX: класть $=$ PAST1 $=1$ PL

'Мы мешок притащили ближе к дому'.

8. Постлативный вариант модели $\left\{\mathrm{N}^{\mathrm{S}}\right.$ ${ }_{\text {Nom }}^{\text {causr }} \mathrm{N}_{\text {OC-causv }}$ Postlat $\left.\mathrm{V}_{\text {caus }}^{\text {fin }}\right\}$ - «перемещение объекта за заднюю часть предмета». Локализатор выражен именем существи-

тельным в сочетании со служебным именем кистінзер 'за заднюю сторону, часть чего-л.' : 
(15) Тӧгені хазаа кистінзер сӧортеп салтырлар
Тӧге $=$ ні
хазаа $=\varnothing$
кист $=\mathrm{i}=$ нзер
сӧӧрте $=$ п
сал=тыр=лар
Бревно $=$ ACC $\quad$ стайка $=\mathrm{NOM} \quad$ за $=\mathrm{POSS} / 3=\mathrm{LAT}$
тащить $=\mathrm{CV} 1$

AUX: класть $=$ PAST $2=\mathrm{PL}$

'Бревно, оказывается, перетащили за стайку'.

9. Интерлативный вариант модели $\left\{\mathrm{N}^{\mathrm{S}-}\right.$ ${ }_{\text {NOM }}^{\text {causr }} \mathrm{N}^{\text {Ob-causv }}{ }_{\text {ACC }}$ Interlat $\left.\mathrm{V}_{\text {caus }}\right\}-$ «nе $\}$ «перщение объекта в пространство между предметами». Локализатор выражен именем су-

ществительным в сочетании со служебным именем аразынзар 'в пространство между предметами':

(16) Мин інектерні агас аразынзар сӥрібіскем
Мин $=0 \quad$ інек $=$ тер $=$ ні
ағас $=0$
Я=NOM $\quad$ корова $=\mathrm{PL}=\mathrm{ACC}$
дерево $=\mathrm{NOM}$
ара $=3 ы=$ нзар
сӱр $=і$ iбic $=\kappa e=M$
промежуток $=\mathrm{POSS} / 3=\mathrm{LAT}$
гнать $=\mathrm{PFR}=\mathrm{PAST} 1=1 \mathrm{Sg}$
‘ Я Я угнал коров в лес'.

10. Сублативный вариант модели $\left\{\mathrm{N}^{\mathrm{s}-}\right.$

тор выражен именем существительным в ${ }_{\text {NOM }}^{\text {causr }} \mathrm{N}^{\text {Ob-causv }}{ }_{\text {ACC }}$ Subllat $\left.\mathrm{V}_{\text {caus }}^{\text {fin }}\right\}-$ «перемещение объекта подо что-либо». Локализа-

сочетании со служебным именем алтынзар 'под низ чего-либо':

(17) Пу нимені стол алтынзар чылдыр салганнар [Чарков 1994: 61]
$\Pi y=0$
ниме $=$ ні
стол $=0$
алт $=\mathbf{=}=$ нзар
чыл=дыр
Это $=\mathrm{NOM}$
что $=$ ACC
стол $=\mathrm{NOM}$
низ $=\mathrm{POSS} / 3=\mathrm{LAT}$
двигаться=CAUS
сал $=$ ған $=$ нар
класть=PAST1 $=$ PL
‘Эту вещь подвинули под стол'.

(18) Айна оолахты таz алтынзар тартыпча [Хакасские народные 1986: 4]
Айна $=0$
оолах $=$ ты
тағ $=0$
алт $=$ = $=$ нзар
тарт $=$ ып=ча
Черт $=\mathrm{NOM} \quad$ мальчик $=\mathrm{ACC} \quad$ гора $=\mathrm{NOM}$
низ $=\mathrm{POSS} / 3=\mathrm{LAT}$
тянуть $=\mathrm{CV} 1=\operatorname{Pr} 2$

'Черт тянет мальчика под гору'.

11. Медилативный вариант модели $\left\{\mathrm{N}^{\mathrm{s}}\right.$ ${ }_{\text {NOM }}^{\text {causr }} \mathrm{N}^{\text {Ob-causv }}{ }_{\text {ACC }}$ Medilat $\left.\mathrm{V}_{\text {перемещения }}\right\}-$ «Перемещение объекта в середину чего-либо».

Локализатор выражен именем существительным в сочетании со служебным именем ортызынзар 'в середину чего-л.'

(19) Піс столны пол ортызынзар чылдыр салгабыс [Чарков 1994: 57]
$\Pi i c=0$
стол=ны
пол $=0$
орт $=$ ы $=$ зы $=$ нзар
чыл=дыр
$\mathrm{Mb}=\mathrm{NOM}$
стол $=\mathrm{ACC} \quad$ пол $=\mathrm{NOM}$
середина $=\mathrm{POSS} / 3=\mathrm{LAT}$
двигаться=CAUS

сал $=$ ға $=$ быс

AUX: класть $=$ PAST $1=1 \mathrm{PL}$

'Мы подвинули стол в середину комнаты'.

2. Модель делокативного перемещения $\left\{\mathrm{N}^{\mathrm{S}-\mathrm{CAUSR}}{ }_{\text {NOM }} \mathrm{N}^{\mathrm{Ob}-\mathrm{CAUSV}}{ }_{\text {ACC }}\right.$ Deloc $\left.\mathrm{V}_{\text {caus }}^{\text {cin }}\right\}$ «перемещение объекта субъектом-каузатором из исходной точки»

Модель делокативного перемещения представляет перемещение каузируемого объекта по направлению от какой-либо точки в пространстве без конкретизации конеч- ной точки. В состав модели входят четыре компонента: 1) субъект-каузатор; 2) объект-каузатив; 3) делокативный локализатор; 4) предикат перемещения. Субъект-каузатор выражен именем существительным в именительном падеже, обозначающим лицо, также название какой-либо стихии (чаще ветер, вода). Объект-каузатив - име- 
нами, обозначающими лицо или предмет. Локализатор данной модели выражен именем существительным в исходном падеже, существительными в сочетании с послелогами и служебными именами в исходном падеже, а также дейктическими локативнми наречиями.

Предикаты выражены глаголами перемещения: aл nap-/ anap- 'нести, везти', авыл- 'принести, привести', сӧзір- '1) тащить, тянуть, волочить кого-л., что-л.; 2) тянуть на буксире', сӥр- 'гнать, выгонять', im'толкать', хоста- 'гнать, отгонять кого-л.', cblzap- 'выводить, выгонять кого-л. поднимать вверх', чьллдыр- 'двигать кого-л., что-л.', кӧзір- 'перемещать, переносить, перетаскивать кого-л., что-л.; перевозить, переселять кого-л., что-л.' [ХРС 2006: 28, 67, $139,195,503,532,541,853,1019]$ и сложными глаголами, образованными от деепричастия cblzapa (cblzapa mapm 'вытягивать', cblzapa сас 'выталкивать', сывара im- 'выталкивать’ и др.), которые служат для выражения перемещения объекта из ограниченного пространства (помещение):

(20) Хызапыйа Сафоновна хайдаz-да «полономочнайны» конторадаң сыzара хостабыcmыр [AT 1988: 28]

$\begin{array}{llll}\text { Хызапыйа=ø } & \text { Сафоновна=0 } & \text { хайдағ-да } & \text { «полономочнай=ны» } \\ \text { Хызапыйа=NOM } & \text { Сафоновна=NOM } & \text { какой=NOM=PRTKL } & \text { «полномочный=ACC» } \\ \text { контора=даң } & \text { сығар=а } & \text { хоста=быс=тыр } & \\ \text { контора=ABL } & \text { выводить=CV2 } & \text { гнать=PFM=PAST2 } & \end{array}$

'Хызапыйа Сафоновна какого-то «полномочного» выгнала из конторы'.

В зависимости от семантики локализа-

ние объекта от говорящего лица». Локалитора мы можем выделить структурно-семантические варианты данной модели: затор выражен дейктическим наречиями мыннаң 'отсюда', тігдең 'оттуда', аннаң

1. Дейктический вариант модели $\left\{\mathrm{N}^{\mathrm{s}-}\right.$ 'оттуда', например: ${ }_{\text {NOM }}^{\text {causr }} \mathrm{N}_{\text {ACC }}^{\text {Ob-causv }}$ Deis $\left.\mathrm{V}_{\text {caus }}^{\text {caus }}\right\}-$ «перемеще-

(21) Олар таңда мині мыннаң апарыбызарлар [Татарова 1991: 163]

$\begin{array}{lllll}\text { Олар }=\varnothing & \text { таң=да } & \text { мин=і } & \text { мын=наң } & \text { апар=ыбыз =ap=лар } \\ \text { Они=NOM } & \text { заря=LOC } & \text { я=ACC } & \text { это=ABL } & \text { увозить }=\mathrm{PFV}=\mathrm{FUT}=\mathrm{PL}\end{array}$

'Они завтра увезут меня отсюда'.

2. Апудаблативный вариант модели. Данный вариант имеет две разновидности:

a) $\left\{\mathrm{N}^{\mathrm{S} \text {-causr }}{ }_{\text {NOM }} \mathrm{N}^{\text {Ob-causv }}{ }_{\text {ACC }}\right.$ Apudablat $_{1}$ $\left.\mathrm{V}_{\text {caus }}^{\text {cin }}\right\}$ - «перемещение объекта от сторо- ны пространственного ориентира». Локализатор выражен именем существительным в исходном падеже в сочетании с послелогом cblzapa 'от', например:

(22) Мин пу хапты пеер ибдең сыгара сӧӧртеп килгем

\begin{tabular}{|c|c|c|c|c|}
\hline Мин=ø & пу $=\varnothing$ & хап=ты & иб=дең & сығара \\
\hline $\begin{array}{l}\text { Я=NOM } \\
\text { cööpтe=ח }\end{array}$ & $\begin{array}{l}\text { это }=\mathrm{NOM} \\
\text { кил }=\mathrm{re}=\mathrm{M}\end{array}$ & мешок $=\mathrm{ACC}$ & дом $=\mathrm{ABL}$ & из=POSTP \\
\hline тащить $=\mathrm{CV} 1$ & AUX: при & $\mathrm{Tb}=\mathrm{PAST} 1=1 \mathrm{~S}$ & & \\
\hline
\end{tabular}

б) $\left\{\mathrm{N}_{\text {NOM }}^{\mathrm{S} \text {-causr }} \mathrm{N}^{\text {Ob-causv }}{ }_{\text {ACC }}\right.$ Apudablat $_{2}$ $\left.\mathrm{V}_{\text {caus }}{ }_{\text {fin }}\right\}-$ «перемещение объекта от края, основания чего-либо». Локализатор выражен именем существительным в сочетании со служебными именами хыринаң 'от края', хазынаң, 'от берега, от края дороги', тӧзінең 'от основания дерева, горы':

(23) Піс пу тегілекті чол хазынаң іт килгебіс
$\Pi i c=0$
пу $=0$
тегілек $=$ ті
чол $=0$
хаз=ы=наң
$\mathrm{Mb}=\mathrm{NOM}$
это $=\mathrm{NOM}$
колесо $=$ АCC
дорога $=\mathrm{NOM}$
край $=\mathrm{POSS} / 3=\mathrm{ABL}$

кил $=$ ге $=$ біс 
толкать $=\mathrm{CV} 1 \quad$ AUX: приходить $=$ PAST1 $1=1 \mathrm{PL}$

'Мы это колесо прикатили от края дороги'.

3. Супераблативный вариант модели Локализатор выражен именем существи$\left\{\mathrm{N}^{\mathrm{S} \text {-causr }}{ }_{\text {Nom }} \mathrm{N}_{\text {OC-causv }}^{\text {OCC }}\right.$ Superablat $\left.\mathrm{V}_{\text {caus }}{ }_{\text {fin }}\right\}-$ тельным в исходном падеже в сочетании с «перемещение объекта откуда-либо вниз». послелогом тӥзіре 'вниз':

(24) Мин аны тагдаң тӥзіре сазыбысхам

$\begin{array}{lllll}\text { Мин }=0 & \text { a=ны } & \text { тағ=даң } & \text { тӱзіре } & \text { саз=ыбыс }=\text { ха }=\text { M } \\ \text { Я=NOM } & \text { он=ACC } & \text { гора=ABL } & \text { вниз=POSTR } & \text { толкать=PFG=PAST1=1Sg } \\ \text { 'Я его толкнул с горы’. } & & \end{array}$

4. Аутаблативный вариант модели $\left\{\mathrm{N}^{\mathrm{s}-}\right.$ ${ }_{\text {NOM }}^{\text {causr }} \mathrm{N}^{\text {Ob-causv }}{ }_{\text {ACC }}$ Autablat $\left.\mathrm{V}_{\text {caus }}^{\text {can }}\right\}-\ll \Pi$ -

Локализатор выражен наречием macхapмещение объекта снаружи в помещение».

\section{(25) Паша пу хапты тасхартын сӧӧртеп килген}

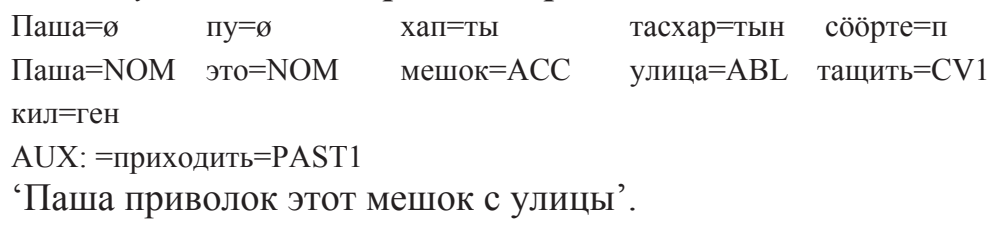

5. Инаблативный вариант модели. В за«перемещение объекта из замкнутого провисимости от семантики локализатора данный вариант имеет две разновидности: странства». Локализатор выражен именем в исходном падеже, обозначающим какое-лиa) $\left\{\mathrm{N}_{\text {SOM }}^{\mathrm{S} \text {-causr }} \mathrm{N}_{\text {No-causv }}^{\text {OCC }}\right.$ Inablat $\left.{ }_{1} \mathrm{~V}_{\text {fin }}^{\text {caus }}{ }_{\text {fin }}\right\}-$ бо замкнутое пространство, например:

(26) Піс столны турадаң сызар килгебіс

$\begin{array}{llll}\text { Пiс=ø } & \text { стол=ны } & \text { тура=даң } & \text { сығ=ар } \\ \text { Мы=NOM } & \text { стол=ACC } & \text { дом=ABL } & \text { выходить=IMP } \\ \text { кил=ге=біс } & & & \end{array}$

AUX: приходить $=$ PAST $=1 \mathrm{PL}$

'Мы стол вынесли из дома'.

б) $\left\{\mathrm{N}^{\mathrm{S} \text {-causr }}{ }_{\mathrm{NOM}} \mathrm{N}^{\text {Ob-causv }}{ }_{\mathrm{ACC}}\right.$ Inablat $\left.{ }_{2} \mathrm{~V}_{\text {caus }}{ }_{\text {fin }}\right\}$ - «перемещение объекта из внутренней части объемного пространства». Локализатор

выражен именем в именительном падеже в сочетании со служебным именем істінең

(27) Мин хоосхачуахты шкаф істінең сывар килгем

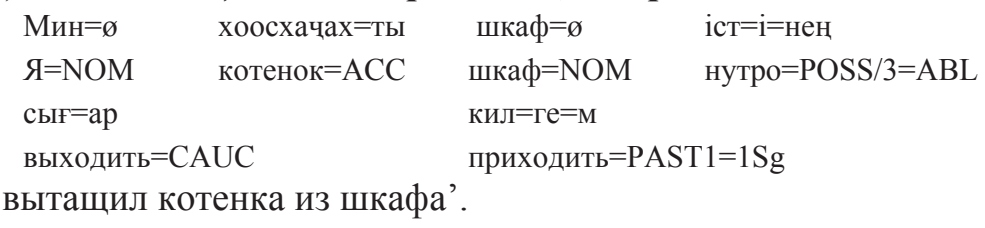

Кроме того, служебное имя icmi может употребляться в форме двойного падежа (направительного - =зер и древнего исслучае говорится о перемещении объекта не из самой внутренней части объемного про-

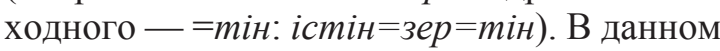
странства, а со стороны внутренней части объемного пространства, например:

(28) Гриша чылгызын ӧзен істінзертін сӱр килген [Чарков 1994: 146]

$\begin{array}{ll}\text { Гриша }=\varnothing & \text { чылғы }=3 \mathrm{I}=\mathrm{H} \\ \text { Гриша }=\mathrm{NOM} & \text { лошадь }=\mathrm{POSS} / 3=\mathrm{ACC}\end{array}$

ӧзен= $=$
лог $=\mathrm{NOM}$


$\mathrm{ic} \mathrm{T}=\mathrm{i}=\mathrm{H}$ ер $=$ тін нутро $=\mathrm{POSS} / 3=\mathrm{LAT}=\mathrm{ABL}$

\section{cÿр $=\varnothing$}

гнать $=\mathrm{CV}$ кил=ген

AUX: приходить=PAST1

'Гриша пригнал свой табун лошадей со стороны пойменной части ложбины'.

6. Постаблативный вариант модели $\left\{\mathrm{N}^{\mathrm{s}-}\right.$ ${ }_{\text {NOM }}^{\text {causr }} \mathrm{N}_{\text {ACC }}^{\text {Ob-causv }}$ Postablat $\left.\mathrm{V}_{\text {caus }}^{\text {can }}\right\}-$ «перемещение объекта из-за задней части пред- мета». Локализатор выражен именем существительным в сочетании со служебными именами кистінең 'из-за', например:

(29) Тӧгені хазаа кистіннең сӧӧртеп килтірлер [АТ 1988: 10]
Тӧге $=$ ні
хазаа $=\varnothing$
кист $=\mathrm{i}=$ нең
сӧӧрте $=\Pi$
Бревно $=\mathrm{ACC}$
стайка=NOM
$3 \mathrm{a}=\mathrm{POSS} / 3=\mathrm{ABL}$
тащить $=\mathrm{CV} 1$
кил=тір $=$ лер
AUX: приходить $=$ PAST2 $=3$ PL
'Бревно, оказывается, притащили из-за стайки'.

7. Интераблативный вариант модели $\left\{\mathrm{N}^{\mathrm{S} \text {-causr }}{ }_{\text {NOM }} \mathrm{N}^{\text {Ob-causv }}{ }_{\text {ACC }}\right.$ Interablat $\left.\mathrm{V}_{\text {caus }}^{\text {fin }}\right\}-\ll \Pi$ ремещение объекта из промежутка между чем-либо». Локализатор выражен именем существительным в сочетании со служебными именами аразынаң 'из промежутка между чем-либо', например:

(30) Мин інектерні агас аразынаң сызар килгем

\begin{tabular}{|c|c|c|c|}
\hline Мин=ø & інек=тер=ні & aғac $=\varnothing$ & ара $=3 ы=$ наң \\
\hline $\mathrm{S}=\mathrm{NOM}$ & корова $=\mathrm{PL}=\mathrm{ACC}$ & дерево=NOM & промежуток=POSS $/ 3=\mathrm{ABL}$ \\
\hline сығ=ар & & кил=ге $=$ м & \\
\hline выходить & & приходить $=\mathrm{P}$ & $=1 \mathrm{Sg}$ \\
\hline
\end{tabular}

8. Субаблативный вариант модели $\left\{\mathrm{N}^{\mathrm{s}-}\right.$ ${ }_{\text {NOM }}^{\text {causr }} \mathrm{N}^{\text {Ob-causv }}{ }_{\text {ACC }}$ Subablat $\left.\mathrm{V}_{\text {fin }}^{\text {caus }}\right\}-\ll$ «премещение объекта из-под чего-либо». Лока-

лизатор выражен именем существительным в сочетании со служебными именами алтынаң 'из-под', например:

(31) Пала пу ойначахты стол алтынаң сызар килген

\begin{tabular}{|c|c|c|c|}
\hline Пала=ø & пу $=\varnothing$ & ойначах=ты & стол $=\varnothing$ \\
\hline Ребенок=NOM & это $=\mathrm{NOM}$ & игрушка=ACC & стол $=\mathrm{NOM}$ \\
\hline алт=ы=наң & сығ=ар & кил=ген & \\
\hline низ $=\mathrm{POSS} / 3=\mathrm{ABL}$ & выходить=IMP & приходить=PAST1 & \\
\hline
\end{tabular}

3. Модель транслокативного перемещения $\left\{\mathrm{N}_{\text {NOM }}^{\text {-causr }} \mathrm{N}_{\text {ACC }}^{\text {Ob-causv }}\right.$ Trloc $\left.\mathrm{V}_{\text {caus }}^{\text {fin }}\right\}$ «перемещение объекта по какой-либо поверхности»

Модель трансклокативного перемещения представляет перемещение каузируемого объекта по какой-либо поверхности. В состав модели входят четыре компонента: 1) субъект-каузатор; 2) объект-каузатив; 3) транслокативный локализатор; 4) предикат перемещения. Субъект выражен одушевленными именами в именительном падеже. Объект - одушевленными и неодушевленными именами. Локализатором данной мо- дели выступают имена существительные в продольном падеже (показатель - =ча/че,

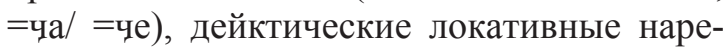
чия, сочетание имен существительных со служебными именами. Предикатом выступают те же глаголы, что и в предыдущих двух моделях.

Например:

В зависимости от семантики локализатора мы выделяем шесть вариантов данной модели.

1. Дейктический вариант модели $\left\{\mathrm{N}^{\mathrm{s}-}\right.$ ${ }_{\text {nOM }}^{\text {causr }} \mathrm{N}_{\text {ACC }}^{\text {Ob-causv }}$ Deis $\left.\mathrm{V}_{\text {fin }}^{\text {caus }}\right\}$ - «перемещение объекта относительно говорящего лица». Локализатор выражен дейктическим 
наречиями мынча 'по тому месту, где находится говорящий', mігче 'по тому (видимому) месту (возможен указательный жест)',

(32) Олар атты тігуе апарыбысханнар [Татарова 1991: 163]

$\begin{array}{llll}\text { Олар }=\varnothing & \text { ат=ты } & \text { тігі=че } & \text { апар=ыбыс=хан=нар } \\ \text { Они=NOM } & \text { конь=ACC } & \text { то=PROLAT } & \text { уводить=PFV=PAST1=PL }\end{array}$

'Они коня вон по тому месту увели'.

2. Суперпролативный вариант модели $\left\{\mathrm{N}_{\text {NOM }}^{\mathrm{S} \text {-causr }} \mathrm{N}_{\text {ACC }}^{\text {Ob-causv }}\right.$ Superprolat $\left.\mathrm{V}_{\text {fin }}^{\text {caus }}\right\}-$ «перемещение каузируемого объекта по поверхности пространственного ориентира». Локализатор выражен именем в про-

(33) Azасты Авбан сувуа индір сыхханнар [AT 1988: 53]

\begin{tabular}{|c|c|c|c|}
\hline Ағас $=$ ты & Ағбан=ø & $c y ғ=4 a$ & ин=дір \\
\hline Дерево $=$ АСС & Абакан=NOM & вода $=$ PROLAT & спускаться=CAUS \\
\hline сых=хан=нар & & & \\
\hline AUX: выходит & $\mathrm{ST} 1=\mathrm{PL}$ & & \\
\hline 'Лес стали & лять по рекє & & \\
\hline
\end{tabular}

3. Пролативный вариант модели $\left\{\mathrm{N}^{\mathrm{S}-}\right.$ ${ }_{\text {NOM }}^{\text {causr }} \mathrm{N}_{\text {ACC }}^{\text {Ob-causv }}$ Prolat $\left.\mathrm{V}_{\text {fin }}^{\text {caus }}\right\}$ - «перемещение каузируемого объекта через определенный пространственный ориентир». Локализатор выражен именем существитель- дольном падеже, представляющим собой твердую поверхность, либо водную среду, по которой субъект-каузатор перемещает объект, например:

ным в именительном падеже в сочетании со служебными именами азыра 'через что-л. (обычно возвышенность)', кизіре 'через (реку, дорогу)', например:

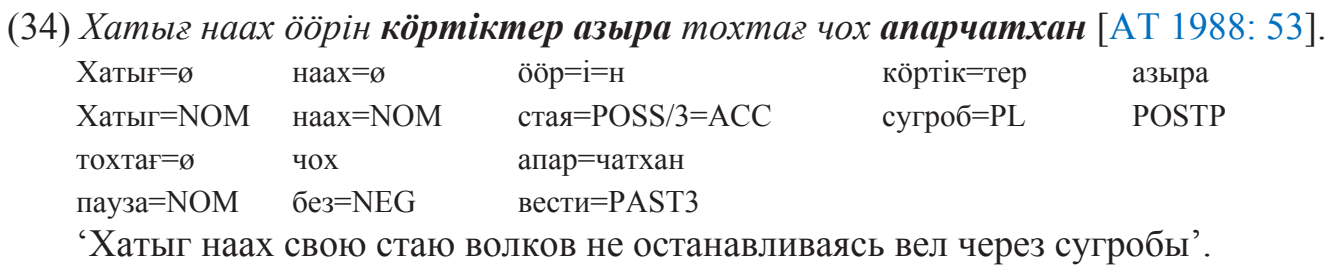

4. Апудпролативный вариант модели $\left\{\mathrm{N}_{\text {NOM }}^{\text {-causr }} \mathrm{N}_{\text {ACC }}^{\text {Ob-causv }}\right.$ Apudprolat $\left.\mathrm{V}_{\text {caus }}^{\text {can }}\right\}-$ «перемещение объекта по краю, основанию чего-либо». Локализатор выражен именем

(35) Піс інектерні арыз хазынча сӥргебіс

\begin{tabular}{|c|c|c|c|}
\hline$\Pi i c=\varnothing$ & & & \\
\hline & & & \\
\hline $\begin{array}{l}\text { Мы=NOM } \\
c \ddot{p}=г е=6 i c\end{array}$ & корова $=\mathrm{PL}=\mathrm{ACC}$ & лес=NOM & край=POSS/3=PROLAT \\
\hline гнать $=$ PAS 1 & & & \\
\hline Мы коро & али вдоль леса & & \\
\hline
\end{tabular}

5. Постпролативный вариант модели $\left\{\mathrm{N}_{\text {NOM }}^{\text {S-causr }} \mathrm{N}_{\text {acc }}^{\text {Obausv }}\right.$ Postprolat $\left.\mathrm{V}_{\text {caus }}^{\text {fin }}\right\}-$ «перемещение объекта вдоль задней части предмета». Локализатор выражен именем

(36) Пу тӧгені хазаа кистінче сӧӧртеп килгебіс

$\begin{array}{llll}\text { Пу }=\varnothing & \text { тӧге }=\text { ні } & \text { хазаа }=\varnothing & \text { кист }=\mathrm{i}=\text { нче } \\ \text { Это=NOM } & \text { бревно=ACC } & \text { стайка=NOM } & \text { за=POSS } / 3=\text { PROLAT }\end{array}$

$$
\begin{array}{llll}
\text { Пу }=\varnothing & \text { тӧге }=\text { ні } & \text { хазаа }=\varnothing & \text { кист }=\mathrm{i}=\text { нче } \\
\text { Это }=\mathrm{NOM} & \text { бревно }=\mathrm{ACC} & \text { стайка }=\mathrm{NOM} & \text { за=POSS } / 3=\text { PROLAT }
\end{array}
$$

существительным в сочетании со служебными именами кистінче 'вдоль задней части', например: существительным в сочетании со служебными именами хыринуа 'по краю', хазынча 'вдоль берега, дороги', тӧзінче 'вдоль основания горы', например: 
сӧӧрте $=$ п $\quad$ кил $=$ ге $=$ біс

тащить $=\mathrm{CV} 1 \quad$ приходить $=$ PAST $1=1 \mathrm{PL}$

‘Это бревно притащили из-за стайки'.

6. Интерпролативный вариант модели $\left\{\mathrm{N}_{\text {NOM }}^{\text {S-causr }} \mathrm{N}_{\text {OCC }}^{\text {Ob-causv }}\right.$ Interprolat $\left.\mathrm{V}_{\text {fin }}^{\text {caus }}\right\}$ - «перемещение объекта вдоль по пространству между множеством предметов (деревья, дома и т.п.)». Локализатор выра- жен именем существительным в сочетании со служебным именем аразынча 'вдоль по пространству между множеством предметов', например:

(37) Мин адымны арыз аразынча чидін килгем

\begin{tabular}{|c|c|c|}
\hline Мин=Ø & ад=ым=ны & арығ $=\varnothing$ \\
\hline S=NOM & конь $=\mathrm{POSS} / 1=\mathrm{ACC}$ & лес $=$ Nom \\
\hline чидін & кил=ге = & \\
\hline вести $=\mathrm{CV} 1$ & приходить $=\mathrm{PAST} 1=1 \mathrm{Sg}$ & \\
\hline
\end{tabular}

\section{Заключение}

Все вышеизложенное позволяет заключить, что для хакасского языка можно выделить три типа моделей каузируемого перемещения объекта в пространстве: адлокативную, делокативную и транслокативную. Каждая модель обладает структурно-семантическими вариантами. Обусловлено такое варьирование способом выражения локализатора. Так, служебные имена пространственной семантики, которые входят в состав именной группы локализаторов, конкретизируют направление перемещения каузируемого объекта относительно передней, задней, внешней, внутренней части предмета или края, основания чего-либо. Дейктические наречия в составе локализатора характеризуют направление перемещения относительно говорящего лица.

Также в значительной степени такие модели определяются семантикой предиката перемещения. Например, предикат кир 'вводить' служит для образования модели перемещения внутрь пространственного ориентира, cығар 'выводить' - перемещение объекта изнутри пространственного ориентира. Кроме того, сложные глаголы, образованные посредством деепричастия

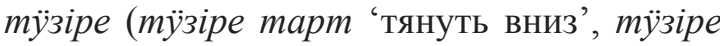
cac 'толкать вниз', mӥзіре im- 'толкать, двигать вниз') вносят характеристику направления движения сверху вниз; cығара - направление движения изнутри (cblzapa сӱр 'выгонять', cblzapa im 'выталкивать' и др.), кире - направление движения внутрь ограниченного пространства (кире im 'передвигать внутрь', кире сас 'толкать внутрь' и др.).

\author{
apa $=$ зы $=$ нча \\ промежуток $=\mathrm{POSS} / 3=\mathrm{PROLAT}$
}

Следует учитывать и тот факт, что в хакасском языке независимо от того, совершается ли перемещение вниз, вперед, в сторону, они могут оформляться как направительным, так и дательным падежом. Направительный падеж в хакасском языке (=зар/=зер; =cap/=cep) имеет значение 'направления движения в сторону пространственного ориентира', не достигая поставленной цели, в то время как дательный падеж $(=$ га/=ге; $=\mathrm{xa} /=\kappa e ;=\mathrm{a} /=\mathrm{e})$ указывает на целенаправленное перемещение по направлению к пространственному ориентиру (ср. apblz=зар апар 'вести в сторону леса' и $a p b l=z a$ anap 'вести в лес (целенаправленно)'. Исключением является терминативный вариант модели, в которой локализатор перемещения оформляется послеложным сочетанием (синонимичные послелоги читіре 'до' и теере 'до' + имя существительное в дательном падеже), например, иб=ге читіре 'до дома', $a p b l=z a$ mеере 'до леса' и др.

\section{Условные обозначения}

$\mathrm{N}_{\text {Noм }}^{\text {S-causr }}-$ субъект-каузатор, $\mathrm{N}_{\text {ACC }}^{\text {Ob-causv }}-$ объект-каузатив; локализаторы: Adloc — адлокативный, Antablat - антаблативный, Autlat - аутлативный, Apudllat - апудлативный, Apudablat - апудаблативный, Autablat - ayтаблативный, Apudprolat - апудпролативный, Dir-lat - директивный, Deloc - делокативный, Deis - дейктический, Illat - иллативный, Interlat - интерлативный, Inablat - инаблативный, Interablat - интераблативный, Interprolat - интерпролативный, Medilat - медилативный, Postlat - постлативный, Postablat - постаблативный, Prolat - пролативный, Postprolat - постпролативный, Subllat 
- сублативный, Subabllat - субаблативный, Superablat - супераблативный, Superprolat суперпролативный, Termin - терминативный, Trloc - транслокативный; $\mathrm{V}_{\text {caus }}^{\text {fin }}$ - предикат перемещения, выраженный глаголом перемещения в финитной форме; кач. - качинский диалект хакасского языка; разг. - разговорный

Грамматические значения в глоссах $1 \mathrm{Sg}$ - личный аффикс 1-го л. ед. ч.; $1 \mathrm{PL}$ - личный аффикс 1-го л. мн. ч.; АCC - винительный падеж; ABL - исходный падеж; AUX - вспомогательный глагол; NOM — неопределенный падеж; DAT - дательный падеж; GEN — притяжательный (родительный) падеж; LAT — направительный падеж; LOC — местный падеж; PROLAT — продольно-направительный падеж;

\section{Источники}

АТ 1988 - Ах тасхыл (литературно-художественный альманах). Абакан: Хакасское отд-е Красноярского кн. изд-ва, 1988. № 36. $142 \mathrm{c.}$

Балтыжаков 1975 - Балтыжжаков Т. Орис. Абакан: Хакасское отд-е Красноярского кн. издва, 1975. 67 с.

Султреков 2009 - Султреков $A$. Кӧглепчеткен ағас (= Поющее дерево) / на хак. яз. Абакан: Хакасское кн. изд-во, 2009. 180 с.

Татарова 1991 - Татарова В. Аат табызы. Абакан: Хакасское отд-е Красноярского кн. издва, 1991. $232 \mathrm{c}$

Чарков 1994 - Чарков С. Ах Ӱ̈̈с хазында. (= На берегу Белого Июса). Сборник рассказов. Абакан: Хакасское кн. изд-во, 1994. 176 с.

Халларов 1984 - Халларов A. Акай. Абакан: Хакасское отд-е Красноярского кн. изд-ва, 1984. $184 \mathrm{c}$.

Хакасские народные 1986 - Хакасские народные сказки. На хак. яз. (Сост. В. И. Доможаков). Абакан: Хакасское отд-е Красноярского кн. изд-ва, 1986 г. 144 с.

\section{Литература}

Апресян 1995 - Апресян Ю. Д. Избранные труды. Т. II. Интегральное описание языка и системная лексикография. М.: Вост. лит., $1995.767 \mathrm{c}$.

Байжанова 2004 - Байжанова Н. Р. Модели элементарных простых предложений в алтайском языке. Структурная схема $\mathrm{N} 1<=>\mathrm{Vf}$ в алтайском языке. Новосибирск: Наука, 2004. $176 \mathrm{c}$.

Дурова 2016 - Дурова М. В. Модели бытийно-пространственных элементарных про-
CAUS - понудительный залог; CV1 - форма соединительного деепричастия на $=$ п (полная и усеченная форма); CV2 - форма слитного деепричастия на -a; IMP - повелительное наклонение; NEG - отрицание; PAST1 - форма прошедшего на =ган; PAST2 - форма прошедшего на =тыр; PAST3 - форма прошедшего на =ды; $\operatorname{Pr} 1$ - форма настоящего времени на =ир; Pr2 - форма настоящего времени на =ча; FUT — форма будущего на =ap; POSS - аффикс принадлежности; POST - послелог; PL множественное число; PTCL - частица; PFV - маркер совершенного вида; Ø - нулевая морфема; = - морфемный шов при словоизменительных и формообразовательных аффикcax; / - разграничитель значений в комплексной морфеме

стых предложений в японском языке (в сопоставлении с языками народов Сибири): дисс. ... канд. наук. Новосибирск, 2016. $198 \mathrm{c}$.

Дурова 2012 - Дурова М. В. Предложения перемещения в японском языке // Сибирский филологический журнал. 2012. № 3. С. 177183.

Кошкарева 2004 - Кошкарева Н. Б. Пропозиция и модель (на примере предложений перемещения в уральских и тунгуссо-манчжурских языках Сибири) // Гуманитарные науки в Сибири. Сер.: Филология. Новосибирск, 2004. № 4. С. 70-81.

Кошкарева 2005 - Кошкарева Н. Б. Синтаксические средства выражения пространственных отношений (на материале уральских и тунгусо-маньчжурских языков Сибири) // Пути формирования лингвистического ландшафта Сибири / отв. ред.: д-р филол. наук Н. Н. Широбокова. Новосибирск: ООО «Ника», 2005. С. 74-117.

Кошкарева 2006 - Кошкарева Н. Б. Метод моделирования структуры и семантики элементарного простого предложения как единицы языка // Вестник Новосибирского государственного университета. Серия: Лингвистика и межкультурная коммуникация. 2006. Т. 4. Вып. 2. С. 64-76.

Кошкарева 2019 - Кошкарева Н. Б. Акциональные предложения в хантыйском и ненецком языках: семантика и пути метафоризации // Сибирский филологический журнал. 2019. № 4. C. 267-280.

Невская 1997 - Невская И. А. Типология локативных конструкций в тюркских языках Южной Сибири (на материале шорского 
языка): автореф. дисс. ... д-ра филол. наук. Новосибирск, 1997. 45 с.

Невская 2005 - Невская И. А. Пространственные отношения в тюркских языках Южной Сибири (на материале шорского языка). Новосибирск: ООО «Ника», 2005. 305 с.

Озонова 2012 - Озонова A. А. Предложения адлокативного движения и перемещения и образуемые ими модели в тюркских языках Южной Сибири (на материале алтайского и хакасского языков) // Основные тенденции развития алтаистики в изменяющихся мировоззренческих условиях: мат-лы междунар. науч.-практ. конф., посвящ. 1150-летию российской государственности, 90-летию Ойротской автономной области, 60-летию Научно-исследовательского института алтаистики им. С. С. Суразакова. В 2-х ч. отв. ред. Н. М. Екеева. Горно-Алтайск: Горно-Алтайск. тип., 2012. С. 228-233.

Серээдар 1995 - Серээдар H. Ч. Основные типы предложений с именным сказуемым в тувинском языке: автореф. дисс. ... канд. филол. наук. Новосибирск, 1995. 21 с.

Серээдар, Скрибник, Черемисина 1996 Серээдар Н. Ч., Скрибник Е. К., Черемисина М. И. Структурно-семантическая организация предложений наличия, локализации, количества и отсутствия в тюркских языках Южной Сибири. Новосибирск: НГУ, 1996. $82 \mathrm{c}$.

Соловар 1991 - Соловар В. Н. Структурно-семантические типы простого предложения казымского диалекта хантыйского языка: дисс. ... канд. филол. наук. Новосибирск, 1991. $16 \mathrm{c}$.

Соловар 2011 - Соловар В. Н. Парадигма простого предложения в хантыйском языке (на материале казымского диалекта): автореф. дисс. ... д-ра филол. наук. Йошкар-Ола, 2011.39 c.

Скрибник 1990 - Скрибник Е. К. К описанию системы моделей простого предложения в мансийском языке (предложения с именным сказуемым) // Системность на разных уровнях языка. Новосибирск: ИИФФ, 1990. C. $95-125$.

\section{Sources}

[Khakas Folk Tales]. V. I. Domozhakov (comp.). Abakan: Khakas Branch of Krasnoyarsk Book Publ., 1986. 144 p. (In Khak.)

Akh Taskhyl (literary almanac). 1988. No. 36. 142 p. (In Khak.)
Телякова 1994 - Телякова В. Н. Простое предложение в шорском языке в сопоставлении с русским: автореф. дисс. ... канд. филол. наук. Новосибирск, 1994. 22 с.

ХРС - Хакасско-русский словарь / сост. О. П. Анжиганова, Н. А. Баскаков, М. И. Боргояков, А. И. Инкижекова-Грекул, Д. Ф. Патачакова, О. В. Субракова, П. Е. Белоглазов, 3. Е. Каскаракова, А. С. Кызласов, Р. Д. Сунчугашев, М. Д. Чертыкова. Новосибирск: Наука, 2006. 1114 с.

Черемисина 1995 - Черемисина М. И. Элементарное простое предложение в языках Сибири // Гуманитарные науки в Сибири. 1995. № 4. С. 63-68.

Черемисина, Колосова 1987 - Черемисина М. И., Колосова Т. А. Очерки по теории сложного предложения. Новосибирск: Наука, Сибирское отделение, 1987. 197 с.

Черемисина, Озонова, Тазранова 2008 - Черемисина М. И., Озонова А. А., Тазранова А. Р. Элементарное простое предложение с глагольным сказуемым в тюркских языках Южной Сибири / отв. ред. Е. К. Скрибник. Новосибирск: Любава, 2008. 205 с.

Черемисина, Скрибник 1996 - Черемисина M. И., Скрибник Е. К. О системе моделей элементарных простых предложений в языках Сибири // Гуманитарные науки в Сибири. 1996. № 4. С. 46-57.

Чугунекова 2019 - Чугунекова A. Н. Категория пространства в хакасском языке. Абакан: Изд-во ФГБОУ ВО «Хакасск. гос. ун-т им. Н. Ф. Катанова», 2019. 160 с.

Шилова 2003а - Шилова В. В. Пространственные модели элементарных простых предложений в ненецком языке. Новосибирск: НГУ, 2003. Ч. $1.106 \mathrm{c.}$

Шилова 20036 - Шилова В. В. Пространственные модели элементарных простых предложений в ненецком языке. Новосибирск: НГУ, 2003. Ч. 2. 183 с.

Шмелева 1988 - Шмелева Т. В. Семантический синтаксис: Курс лекций. Красноярск: Красноярск. гос. ун-т, 1988. 54 с.

Baltyzhakov T. [Oris]. Abakan: Khakas Branch of Krasnoyarsk Book Publ., 1975. 67 p. (In Khak.)

Charkov S. [By the Side of the Bely Iyus]. Coll. short stories. Abakan: Khakas Book Publ., 1994. 176 p. (In Khak.)

Khallarov A. [Akay]. Abakan: Khakas Branch 
of Krasnoyarsk Book Publ., 1984. 184 p. (In Khak.)

Sultrekov A. [The Singing Tree]. Abakan: Khakas Book Publ., 2009. 180 p. (In Khak.)

Tatarova V. [Aat Tabyzy]. Abakan: Khakas Branch of Krasnoyarsk Book Publ., 1991. 232 p. (In Khak.)

\section{References}

[Khakas-Russian Dictionary]. O. P. Anzhiganova et al. (comps.). Novosibirsk: Nauka, 2006. 1114 p. (In Khak. and Russ.)

Apresyan Yu. D. [Selected Works]. Vol. II: Integral Description of Language and System Lexicography. Moscow: Vostochnaya Literatura, 1995. 767 p. (In Russ.)

Bayzhanova N. R. [Altaian Elementary Simple Sentence Models: N1 $=>$ Vf Structural Scheme]. Novosibirsk: Nauka, 2004. 176 p. (In Russ.)

Cheremisina M. I. Languages of Siberia: elementary simple sentence. Humanitarian Sciences in Siberia. 1995. No. 4. Pp. 63-68. (In Russ.)

Cheremisina M. I., Kolosova T. A. [Essays on the Theory of Complex Sentence]. Novosibirsk: Nauka, 1987. 197 p. (In Russ.)

Cheremisina M. I., Ozonova A. A., Tazranova A. R. [Turkic Languages of South Siberia: Elementary Simple Sentence with Verbal Predicate]. E. K. Skribnik (ed.). Novosibirsk: Lyubava, 2008. 205 p. (In Russ.)

Cheremisina M. I., Skribnik E. K. Languages of Siberia: system of elementary simple sentence models revisited. Humanitarian Sciences in Siberia. 1996. No. 4. Pp. 46-57. (In Russ.)

Chugunekova A. N. [Khakas Language: Category of Space]. Abakan: Katanov Khakas State University, 2019. 160 p. (In Russ.)

Durova M. V. [Models of Existential - Spatial Elementary Simple Sentences in the Japanese Language: in Comparative Perspective with Languages of Siberian Peoples]. Cand. Sc. (philology) thesis. Novosibirsk, 2016. 198 p. (In Russ.)

Durova M. V. Japanese relocation sentences. Siberian Journal of Philology. 2012. No. 3. Pp. 177-183. (In Russ.)

Koshkareva N. B. Actional sentences in the Khanty and Nenets languages: semantics and metaphorization ways. Siberian Journal of Philology. 2019. No. 4. Pp. 267-280. (In Russ.)

Koshkareva N. B. Elementary simple sentence as a language unit: structural and semantic modelling method. NSU Vestnik. Series:
Linguistics and Intercultural Communication. 2006. Vol. 4. No. 2. Pp. 64-76. (In Russ.)

Koshkareva N. B. Expressing spatial relations: syntactic means (a case study of Uralic and Tungus-Manchu languages of Siberia ). In: [Linguistics Landscape of Siberia: Paths of Formation]. N. N. Shirobokova (ed.). Novosibirsk: Nika, 2005. Pp. 74-117. (In Russ.)

Koshkareva N. B. Proposition and model: a case study of relocation sentences in Uralic and Tungus-Manchu languages of Siberia. Humanitarian Sciences in Siberia. Ser. 'Philology'. 2004. No. 4. Pp. 70-81. (In Russ.)

Nevskaya I. A. [Spatial Relations in Turkic Languages of South Siberia: a Case Study of the Shor Language]. Novosibirsk: Nika, 2005. 305 p. (In Russ.)

Nevskaya I. A. [Typology of Locative Constructs in Turkic Languages of South Siberia: a Case Study of the Shor Language]. Dr. Sc. (philology) thesis abstract. Novosibirsk, 1997. 45 p. (In Russ.)

Ozonova A. A. Sentences of adlocative movement / relocation, and their models in Turkic languages of South Siberia: a case study of the Altaian and Khakas languages. In: [Key Development Trends of Altaic Studies in the Context of Changing Worldviews]. Jubilee conf. proc. In 2 vols. N. M. Ekeeva et al. (eds.). Gorno-Altaysk, 2012. Pp. 228-233. (In Russ.)

Sereedar N. Ch. [Sentences with Nominal Predicate in the Tuvan Language: Key Types Revisited]. Cand. Sc. (philology) thesis abstract. Novosibirsk, 1995. 21 p. (In Russ.)

Sereedar N. Ch., Skribnik E. K., Cheremisina M. I. [Sentences of Presence, Localization, Quantity, and Absence in Turkic languages of South Siberia: Structural-Semantic Schemes]. Novosibirsk: Novosibirsk State University, 1996. 82 p. (In Russ.)

Shilova V. V. [Nenets Elementary Simple Sentence: Spatial Models]. Novosibirsk: Novosibirsk State University, 2003. Vol. 1. 106 p. (In Russ.)

Shilova V. V. [Nenets Elementary Simple Sentence: Spatial Models]. Novosibirsk: Novosibirsk State University, 2003. Vol. 2. 183 p. (In Russ.) Shmeleva T. V. [Semantic Syntax]. Coursebook. Krasnoyarsk: Krasnoyarsk State University, 1988. 54 p. (In Russ.)

Skribnik E. K. Mansi simple sentence: system of models revisited (sentences with nominal predicate). In: [Systematicity at Different Language Levels]. Novosibirsk: Institute of 